http://dx.doi.org/10.18778/1643-0700.20.07

Tadeusz MARSZAL*

\title{
ZARYS STRUKTURY OSADNICZEJ REGIONU SZADKOWSKIEGO W 1827 R.
}

Streszczenie. Przeprowadzony w latach 1824-1826 spis ludności i domów, którego wyniki zostały opublikowane w wydanej w 1827 r. Tabelli Miast, Wsi, Osad Królestwa Polskiego pozwala m.in. na zarysowanie struktury osadniczej tej części ówczesnego Królestwa Polskiego, która znajdowała się w ówczesnym powiecie szadkowskim. Pierwsza część opracowania prezentuje syntetyczny obraz osadnictwa w powiecie na podstawie analizy rozmieszczenia ludności i zabudowy mieszkaniowej. W dalszej części artykułu bardziej szczegółowe rozważania poświęcone zostały sieci osadniczej w granicach dzisiejszej gminy Szadek. Struktura sieci osadniczej na tym terenie, ukształtowana do początku XIX w., w znacznym stopniu przetrwała do dziś. Główne zmiany w tym zakresie dotyczą przesunięć w potencjale ludnościowym poszczególnych miejscowości oraz przede wszystkim pojawienia się na mapie nowych punktów osadniczych w wyniku zachodzących od lat 60. XIX w. do połowy XX w. procesów społeczno-ekonomicznych.

Słowa kluczowe: osadnictwo, ludność, region szadkowski

Powiat szadkowski, jeden z czterech w ówczesnym województwie sieradzkim, został utworzony pod koniec XIV w. i obejmował swym zasięgiem 33 parafie. Południowa granica powiatu sięgała Zelowa, zaś północna przebiegała wzdłuż Neru i Warty. Przez kolejne cztery stulecia podział administracyjny, w którym Szadek stanowił istotny element organizacji sieci osadniczej tej części kraju, praktycznie pozostawał bez większych zmian. Dopiero II rozbiór Polski w $1793 \mathrm{r}$. i przeprowadzona pod panowaniem pruskim reorganizacja terytorialna zagarniętych ziem przyniosła ograniczenie terytorialne powiatu szadkowskiego, włą-

* Tadeusz Marszał, prof. dr hab., Uniwersytet Łódzki, Wydział Nauk Geograficznych, Instytut Zagospodarowania Środowiska i Polityki Przestrzennej, 90-142 Łódź, ul. Kopcińskiego 31, e-mail: tadeusz.marszal@geo.uni.lodz.pl. 
czonego do nowoutworzonego departamentu kaliskiego. W okresie Księstwa Warszawskiego (1807-1815) zachowany został podział na departamenty z okresu pruskiego, a granice powiatu szadkowskiego (wchodzącego w skład departamentu kaliskiego ${ }^{1}$ ) wyznaczał od strony północno-wschodniej przebieg Neru, a od południowego-wschodu przebieg Widawki². Po utworzeniu Królestwa Polskiego - kiedy przywrócono stare nazwy jednostek terytorialnych i utworzono województwo kaliskie - powiat szadkowski znalazł się w należącym do województwa kaliskiego obwodzie sieradzkim ${ }^{3}$.

Powstałe w wyniku postanowień kongresu wiedeńskiego Królestwo Polskie - złączone unią personalną z Cesarstwem Rosyjskim - do czasu powstania listopadowego posiadało $\mathrm{w}$ pełni polską administrację. Jednym $\mathrm{z}$ organów administracji publicznej była Komisja Rządowa Spraw Wewnętrznych i Duchownych, w ramach której działał oddział statystyczny, „de facto” pełniący funkcję centralnej instytucji statystycznej i nadzorujący badania oraz opracowujący zestawienia statystyczne Królestwa Kongresowego. Informacje statystyczne zbierały władze administracyjne wszystkich szczebli, które jednak nie prowadziły żadnych analiz pozyskanego zbioru danych, a ich działalność ograniczała się do przekazywania zebranych informacji na szczebel centralny. Poziom wiarygodności gromadzonych materiałów był bardzo różny i zależał od sumienności urzędników niższego szczebla oraz ich ,przygotowania zawodowego". Toteż informacje o charakterze statystycznym dotyczące tego okresu często pozostawiają wiele do życzenia - oprócz ewidentnych i niezamierzonych omyłek zdarzają się materiały zestawione z małą starannością lub dane podawane w dużym przybliżeniu. Tym niemniej nawet tak niedoskonały materiał statystyczny może stanowić cenne źródło informacji, między innymi na temat ówczesnych stosunków ludnościowych i sieci osadniczej.

Pewien obraz struktury osadnictwa w interesującym nas regionie szadkowskim w początkach XIX w. daje spis ludności i domów przeprowadzony na terenie całego Królestwa Polskiego w latach 1824-1826. Wyniki tego spisu zostały opublikowane w wydanej w 1827 r. Tabelli Miast, Wsi, Osad Królestwa Polskiego. W dwóch tomach, w układzie alfabetycznym zostały wyszczególnione wszystkie ówczesne jednostki osadnicze Królestwa Polskiego z podaniem ich przynależności administracyjnej (województwo, obwód, powiat), także z dookreśleniem przynależności parafialnej. Ponadto dla każdej, nawet najmniejszej miejscowości została

1 W skład departamentu kaliskiego wchodziły również powiaty piotrkowski, radomszczański, sieradzki, warciański, wieluński, ostrzeszowski i odolanowski. Zob. Dziennik Prawa Księstwa Warszawskiego, t. I , s. 22-30 [za:] M. Bandurka, Zmiany administracyjne i terytorialne ziem województwa łódzkiego w XIX i XX w., Warszawa 1974, s. 11, 16-17.

2 Zob. M. Turczyn, Szadek na tle podziałów administracyjnych Polski, „Biuletyn Szadkowski" 2001, t. 1, s. 68-70.

3 W skład obwodu sieradzkiego wchodziły dwa powiaty: sieradzki i szadkowski. 
podana liczba ludności i liczba domów, własność w podziale na własność prywatną i rządową oraz położenie geograficzne (odległości od miasta obwodowego ${ }^{4}$ ).

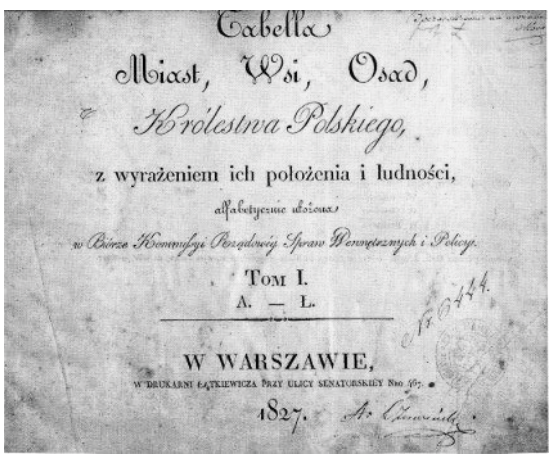

Fot. 1. Strona tytułowa Tabelli Miast, Wsi, Osad Królestwa Polskiego Źródło: fotografia własna, 2019

\section{POWIAT SZADKOWSKI}

Najniższym szczeblem podziału administracyjnego uwzględnionym w spisie miejscowości z 1827 r. są parafie. Na terenie powiatu szadkowskiego funkcjonowały wówczas 23 kościoły parafialne w Borszewicach, Buczku, Drużbinie, Grabnie, Korczewie, Kwiatkowicach, Lutomiersku, Łasku, Małyniu, Marzeninie, Męce, Mikołajewicach, Pabianicach, Pożdżenicach, Restarzewie, Rossoszycy, Sędziejowicach, Strońsku, Szadku, Wierzchach, Wygiezłowie, Zadzimiu i Zduńskiej Woli. Blisko trzydzieści miejscowości pozostających w granicach powiatu szadkowskiego lecz położonych na jego obrzeżach, przynależało do parafii mających swoje siedziby poza powiatem ${ }^{5}$. Większe parafie w regionie liczyły powyżej 20 miejscowości, przy czym na terenie największej z nich - parafii szadkowskiej w 31 miejscowościach mieszkało ponad 5,3 tys. osób. Niewiele mniejsze były parafie w Pabianicach - 29 miejscowości i 5,2 tys. mieszkańców oraz Łasku - 28 miejscowości i 4,2 tys. mieszkańców (por. ryc. 1).

Według spisu z $1827 \mathrm{r}$. w granicach powiatu szadkowskiego znajdowało się blisko czterysta miejscowości. Nakładając współczesny gminny podział administracyjny na mapę obrazującą ich rozmieszczenie widać, iż zasięgiem swym powiat ten obej-

\footnotetext{
4 Odległość ta została podana w milach pocztowych, zwanych inaczej milami pruskimi. Mila pocztowa to odległość jaką pokonywał posłaniec pieszy w czasie 2 godzin drogi (do $1840 \mathrm{r}$. 1 mila pocztowa w przybliżeniu wynosiła $9 \mathrm{~km}$ ).

5 Wśród parafii mających swoje siedziby poza powiatem szadkowskim najwięcej miejscowości z tego powiatu (położonych na jego północnym krańcu) należało do parafii w Bałdrzychowie.
} 
mował praktycznie całe terytorium dzisiejszych 11 gmin, oprócz szadkowskiej, także gminy wiejskie: Zadzimia (39 miejscowości), Łasku (34 miejscowości), Sędziejowic (31 miejscowości), Zduńskiej Woli (22 miejscowości), Zapolic (22 miejscowości), Wodzierad (19 miejscowości), Pabianic (18 miejscowości), Lutomierska (18 miejscowości), Buczka (17 miejscowości) i Dobronia (14 miejscowości). Ponadto do powiatu przynależała znaczna liczba jednostek osadniczych położnych na terenie dalej położonych gmin: Zelowa (20 miejscowości) i Warty (13 miejscowości - mimo iż miasto Warta na początku XIX w. było siedzibą odrębnego powiatu). Do tego zestawu miejscowości powiatu szadkowskiego należy doliczyć jeszcze ponad 30 miejscowości, które zostały w kolejnych dziesięcioleciach XIX i XX w. wchłonięte przez rozrastające się miasta, przede wszystkim Łódź (13 miejscowości) i Zduńską Wolę (7 miejscowości), a także Pabianice, Łask, Sieradz oraz Szadek. Pojedyncze miejscowości leżące na obrzeżach dawnego powiatu szadkowskiego położone są we współczesnych granicach także kilku innych gmin (Poddębice, Pęczniew, Brąszewice, Ksawerów, Rusiec, Burzenin, Sieradz).

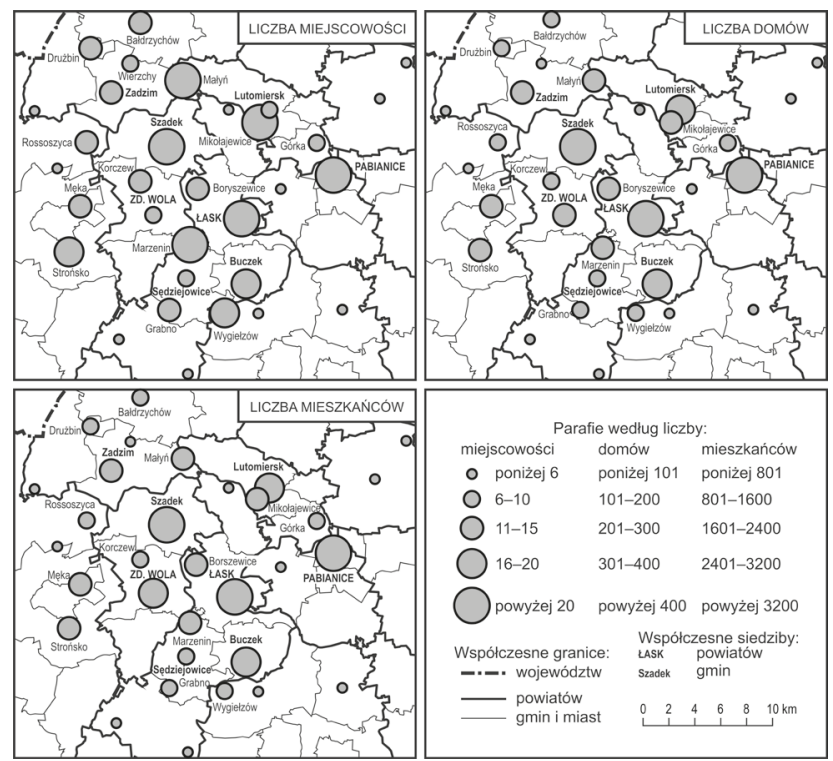

Ryc. 1. Osadnictwo w regionie szadkowskim według parafii ok. 1825 r.

Źródło: opracowanie własne na podstawie Tabella Miast, Wsi, Osad Królestwa Polskiego, z wyrażeniem ich położenia i ludności alfabetycznie ułożona w Biórze Kommisyi Rządowey Spraw Wewnętrznych i Policyi, t. I, II, Warszawa 1827

W początkach XIX w. około 1/5 ogólnej liczby miejscowości powiatu szadkowskiego, przede wszystkim tych położonych przy wschodniej granicy powiatu, było własnością rządową, a pozostałe znajdowały się w rękach prywatnych. Rozkład przestrzenny osadnictwa w powiecie szadkowskim w 1825 r. mierzony 
liczbą miejscowości według położenia w granicach współczesnych gmin, niewiele odbiega od rozmieszczenia zabudowy i ludności (por. ryc. 2).

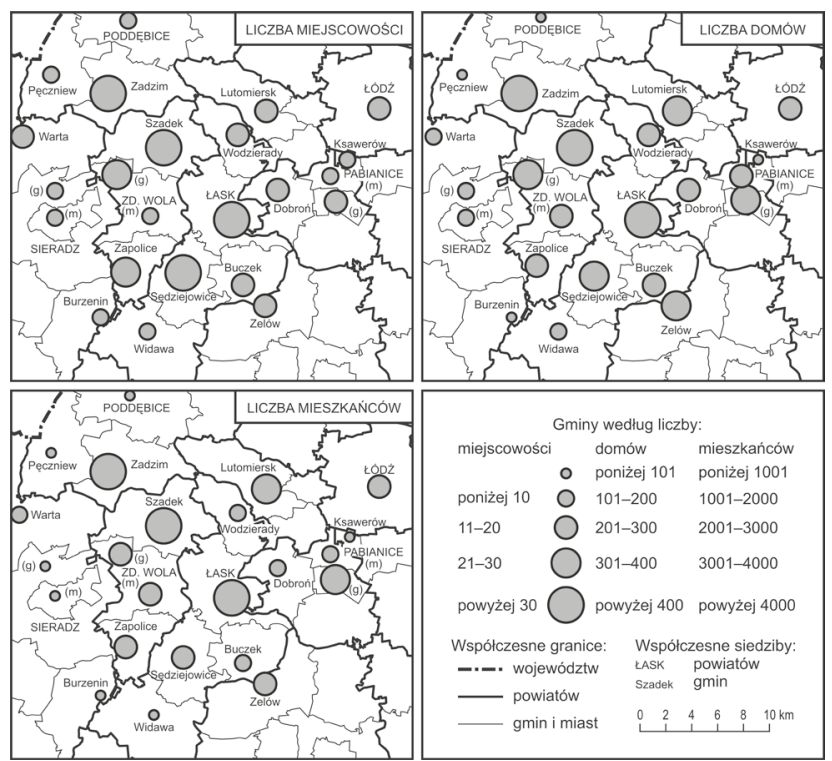

Ryc. 2. Osadnictwo w powiecie szadkowskim ok. 1825 r. według współczesnych gmin

Źródło: opracowanie własne na podstawie Tabella Miast, Wsi, Osad Królestwa Polskiego, z wyrażeniem ich położenia i ludności alfabetycznie ułożona w Biórze Kommisyi Rząowey Spraw Wewnętrznych i Policyi, t. I, II, Warszawa 1827

Potencjał ludnościowy i zabudowy mieszkaniowej (liczba domów) ważniejszych jednostek osadniczych powiatu szadkowskiego na przełomie pierwszego i drugiego ćwierćwiecza XIX w. prezentują ryc. 3 i 4. Układ osadniczy tego regionu miał charakter policentryczny, a rozmieszczenie większych jednostek osadniczych cechowała względna równomierność w pasie centralnym, przy jednoczesnym słabszym rozwoju sieci osadniczej w północnej i południowej części powiatu. Największą jednostka osadniczą, pod względem liczby mieszkańców, był Szadek (2,3 tys.), a niewiele mniejszym potencjałem ludnościowym dysponowały trzy inne miasta regionu liczące 1,8-2,0 tys. mieszkańców (Zduńska Wola, Łask i Lutomiersk).

Rozmieszczenie ludności w zbiorze głównych ośrodków miejskich powiatu dość znacznie odbiega od rozkładu przestrzennego zabudowy, co świadczy o znacznych różnicach w charakterze zabudowy miast, jak i zróżnicowaniu warunków mieszkaniowych. O ile w Łasku, Pabianicach czy Zelowie średnio na jeden budynek mieszkalny przypadło 5,9-6,4 osoby, to w Lutomiersku wskaźnik ten wynosił już 10,3. Jeszcze bardziej niedoinwestowany pod względem zasobów mieszkaniowych był Szadek - 13,7 mieszańca na jeden budynek mieszkalny oraz notująca duży napływ ludności Zduńska Wola-13,2 mieszkańca/budynek (por. ryc. 3 i 4). 


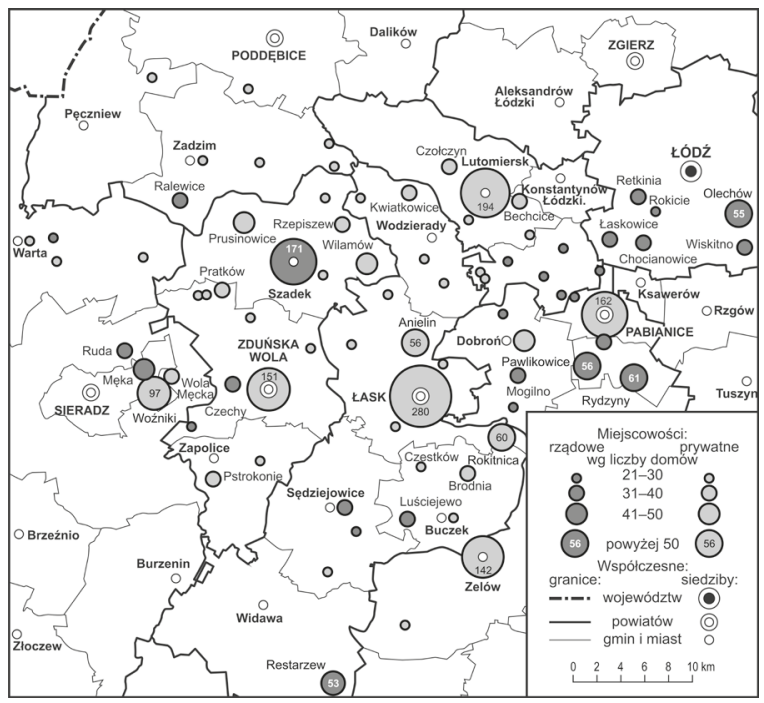

Ryc. 3. Ważniejsze jednostki osadnicze powiatu szadkowskiego ok. 1825 r. według liczby domów

Źródło: opracowanie własne na podstawie Tabella Miast, Wsi, Osad Królestwa Polskiego, z wyrażeniem ich położenia i ludności alfabetycznie ułożona w Biórze Kommisyi Rzqdowey Spraw Wewnętrznych i Policyi, t. I, II, Warszawa 1827

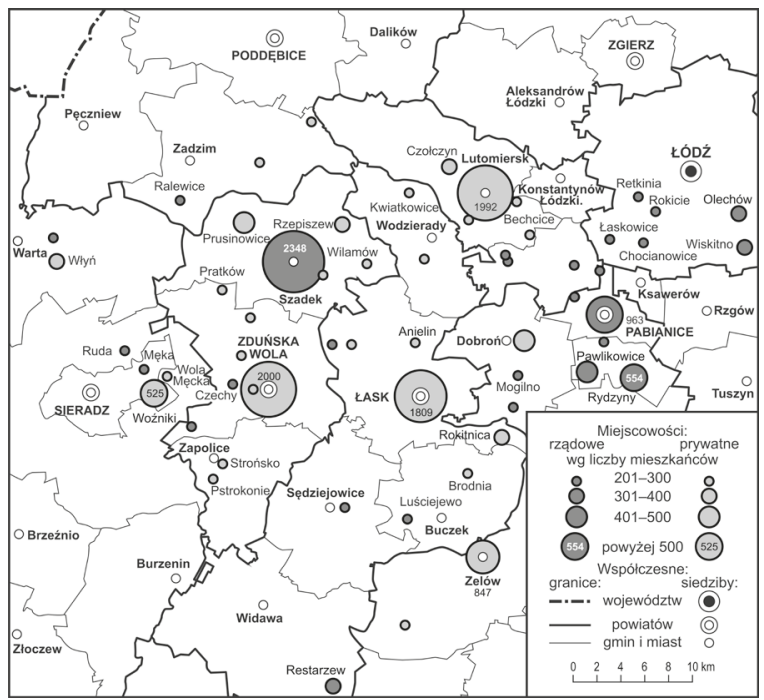

Ryc. 4. Ważniejsze jednostki osadnicze powiatu szadkowskiego ok. 1825 r. według liczby mieszkańców

Źródło: opracowanie własne na podstawie Tabella Miast, Wsi, Osad Królestwa Polskiego, z wyrażeniem ich położenia i ludności alfabetycznie ułożona w Biórze Kommisyi Rzadowey Spraw Wewnętrznych i Policyi, t. I, II, Warszawa 1827 


\section{GMINA SZADEK}

Historia wielu miejscowości położnych na terenie współczesnej gminy Szadek, $z$ reguły lokowanych na prawie niemieckim, sięga średniowiecza. Do najstarszych jednostek osadniczych (nie licząc samego Szadku), istniejących już przed końcem XIV w. należą: Wielka Wieś, Piaski, Szadkowice, Kobyla Miejska, Wilamów i Kromolin Stary. Historia pozostałych, z nielicznymi wyjątkami, sięga okresu $\mathrm{XV}-$ poł. XVI w. ${ }^{6}$ Większość średniowiecznych wsi położonych w pobliżu Szadku stanowiła własność szlachecką, zaś niektóre jak Szadkowice, Wielka Wieś czy Kromolin należały do dóbr królewskich, a później rządowych ${ }^{7}$.

Spis z $1827 \mathrm{r}$. wymienia 37 miejscowości położonych w granicach współczesnej gminy szadkowskiej. W oficjalnym urzędowym wykazie miejscowości z 2015 r. ${ }^{8}$ wymieniowych jest aż 80 nazw miejscowości przypisanych tej gminie (wiele z nich to funkcjonujące zwyczajowe nazwy części wsi), jednak trudno odnaleźć w tym zestawie nazwy niektórych jednostek istniejących dwa wieki temu. W spisie z początku XIX w. obok miasta Szadku jako odrębne jednostki wzmiankowane są Kolblany ${ }^{9}$, Mansyonarya ${ }^{10}$ oraz Bobownia Mieyska - wszystkie współcześnie znajdujące się w granicach miasta. Jednak o ile Bobownia stanowi do dziś rozpoznawalną część Szadku ${ }^{11}$, to pozostałe dwie zanikły. W obowiązującym obecnie spisie miejscowości nie pojawia się także kilka innych nazw istniejących dwieście lat temu i traktowanych jako odrębne jednostki osadnicze, m.in. Bugay (ok. $1825 \mathrm{r}$. 2 domy i 6 mieszkańców) - dawny folwark położony w okolicach współczesnego Antonina, Kobyla Chmielowa (20 domów i 171 mieszkańców) - obecnie część wsi Boczki, Choszczewska Osada (5 budynków i 40 mieszkańców), Chybotel (dwa domy i 10 mieszkańców) - dawne pustkowie ${ }^{12}$ położone koło Rzepiszewa. Niektóre wsie funkcjonujące na początku XIX w. jako odrębne jednostki osadnicze dziś stanowią część składową innych wsi, jak choćby Wola Przatowska (ok. 1825 r. 19 domów i 117 mieszkańców) - obecnie część wsi Piaski.

6 T. Marszał, Gmina Szadek - zarys geograficzny, [w:] T. Marszał (red.), Leksykon solectw gminy Szadek, Łódź-Szadek 2004, s. 11.

7 Kotlinki były własnością kościelną. Więcej na temat historii poszczególnych wsi w gminie szadkowskiej zob. Marszał T. (red.), Leksykon sołectw gminy Szadek, Łódź-Szadek 2004.

8 Obwieszczenie Ministra Administracji i Cyfryzacji z dnia 4 sierpnia 2015 r. w sprawie wykazu urzędowych nazw miejscowości i ich części (Dz.U. z 2015 r., poz. 1636).

9 Kolblany określane też jako Pustkowie Kolbląg (ok. 1825 r. dwa domy i dziewięciu mieszkańców), położone w pobliżu Grabowin.

10 Mansyonaria, zespół budynków zamieszkałych przez mansjonarzy, kapłanów pełniących wyznaczone funkcje duszpasterskie przy katedrach, kolegiatach i znaczniejszych parafiach, a taką była parafia szadkowska. Mansyonaria w Szadku ok. 1825 r. liczyła osiem domów i 45 mieszkańców (z których tylko część była księżmi).

11 Podobnie jak wymienione w spisie z 2015 r. Grabowiny, Krucica, Osiny, Struga, Szadek Poduchowny i Szosa Uniejowska.

12 Pustkowie nie oznacza opustoszałej osady, a zabudowania stojące na uboczu. 


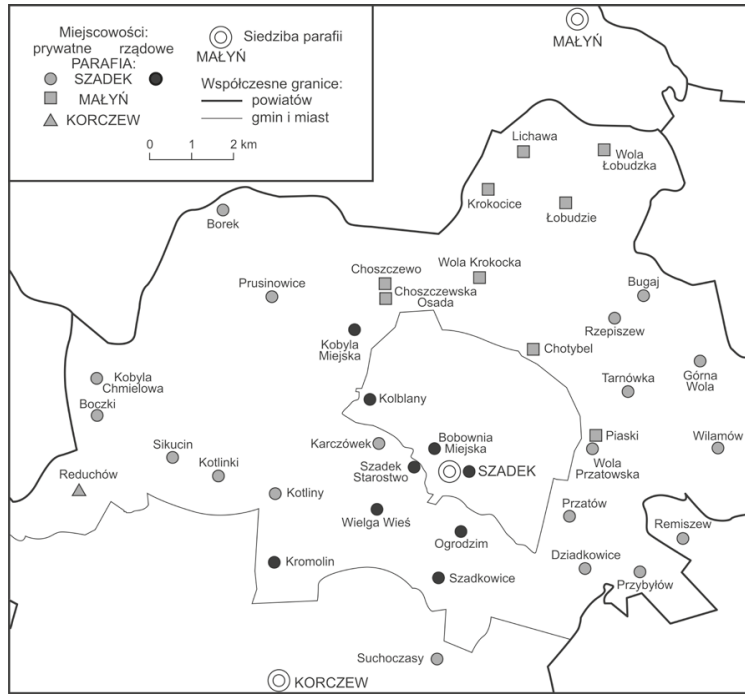

Ryc. 5. Miejscowości gminy szadkowskiej według przynależności parafialnej ok. 1825 r.

Źródło: opracowanie własne na podstawie Tabella Miast, Wsi, Osad Królestwa Polskiego, z wyrażeniem ich położenia i ludności alfabetycznie ułożona w Biórze Kommisyi Rządowey Spraw Wewnętrznych i Policyi, t. I, II, Warszawa 1827

Wsie otaczające Szadek, z wyjątkiem jednej, przynależały do dwóch parafii - te położone w północno-wschodniej części współczesnej gminy, podobnie jak dziś, należały do parafii w Małyniu, pozostałe tworzyły parafię szadkowską ${ }^{13}$ (ryc. 5). W porównaniu z obecnymi granicami administracji kościelnej zmianie uległa jedynie przynależność dwóch wsi, tj. Choszczewa, które niegdyś należało do parafii małyńskiej, a po I wojnie światowej przeszło do parafii szadkowskiej oraz wsi Borki (Borki Prusinowskie) odłączonych w tym samym czasie od parafii szadkowskiej i przyłączonych do parafii w Zygrach ${ }^{14}$. Odrębną historię przynależności parafialnej ma Reduchów, na początku XIX w. wchodzący w skład parafii w Korczewie, a obecnie stanowiący część parafii rossoszyckiej.

Na przełomie pierwszego i drugiego ćwierćwiecza XIX w. wszystkie miejscowości położone w granicach współczesnej gminy szadkowskiej liczyły 632 budynki mieszkalne i nieco ponad 6,3 tys. mieszkańców. Szadek pod względem potencjału demograficznego wyraźnie górował nad pozostałymi otaczającymi

13 Od 1818 r. po zmianie granic diecezjalnych parafia szadkowska, a także małyńska, wcześniej wchodzące w skład archidiecezji gnieźnieńskiej, znalazły się w diecezji kujawsko-kaliskiej (włocławskiej).

14 Zmiana przynależności parafialnej Choszczewa nastąpiła w 1921 r. na wniosek samych mieszkańców wsi, natomiast nie został wówczas uwzględniony protest mieszkańców Borków przeciwko włączeniu tej miejscowości do parafii w Zygrach. Por. P. Szkutnik, Źródła do dziejów Szadku znajdujące się w archiwach kościelnych, „Biuletyn Szadkowski” 2005, t. 5, s. 123. 
to miasto jednostkami osadniczymi, wielokrotnie przewyższając pod względem liczby mieszkańców największą wieś - zamieszkałe przez 0,4 tys. osób Prusinowice. W grupie większych wsi liczących w granicach 0,3 tys. mieszkańców znalazł się także Rzepiszew, Wilamów i Przatów. Blisko 1/3 ogólnej liczby jednostek osadniczych liczyła 50-100 osób, a nieco ponad 1/4 w granicach 100-200 mieszkańców. Osiem wsi położonych w pobliżu zachodniej i południowo-zachodniej granicy miasta stanowiło własność rządową Królestwa Polskiego, a pozostałe były w rękach prywatnych. Wiejskie jednostki osadnicze okolic Szadku pierwszej połowy XIX w. charakteryzowało względnie równomierne rozmieszczenie, z wyjątkiem zalesionego pasa terenu ciągnącego się na północy-zachód od miasta (por. ryc. 6 i 7).

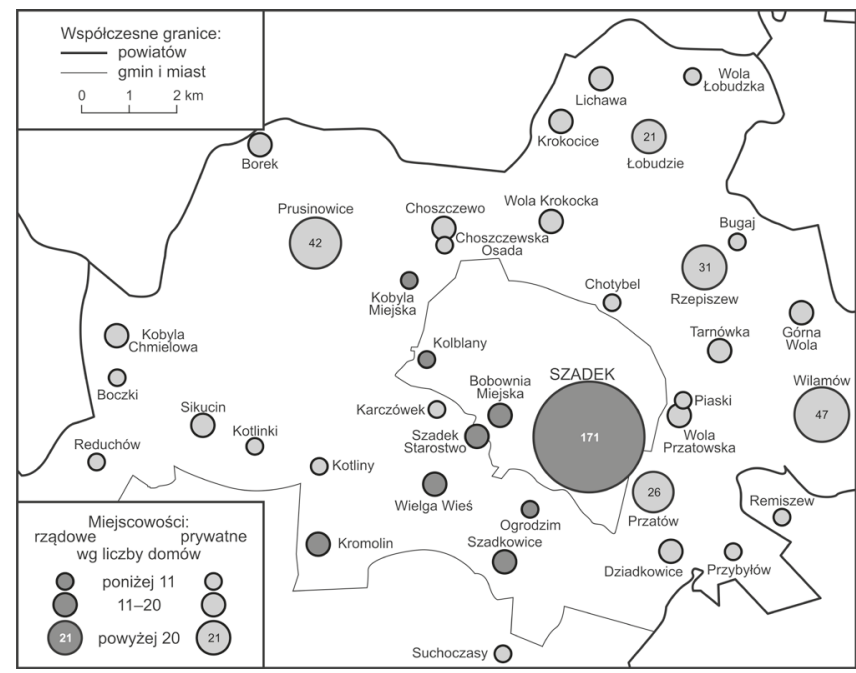

Ryc. 6. Rozkład przestrzenny zabudowy w gminie szadkowskiej według liczby domów ok. $1825 \mathrm{r}$.

Źródło: opracowanie własne na podstawie Tabella Miast, Wsi, Osad Królestwa Polskiego, z wyrażeniem ich położenia i ludności alfabetycznie ułożona w Biórze Kommisyi Rzadowey Spraw Wewnętrznych i Policyi, t. I, II, Warszawa 1827 


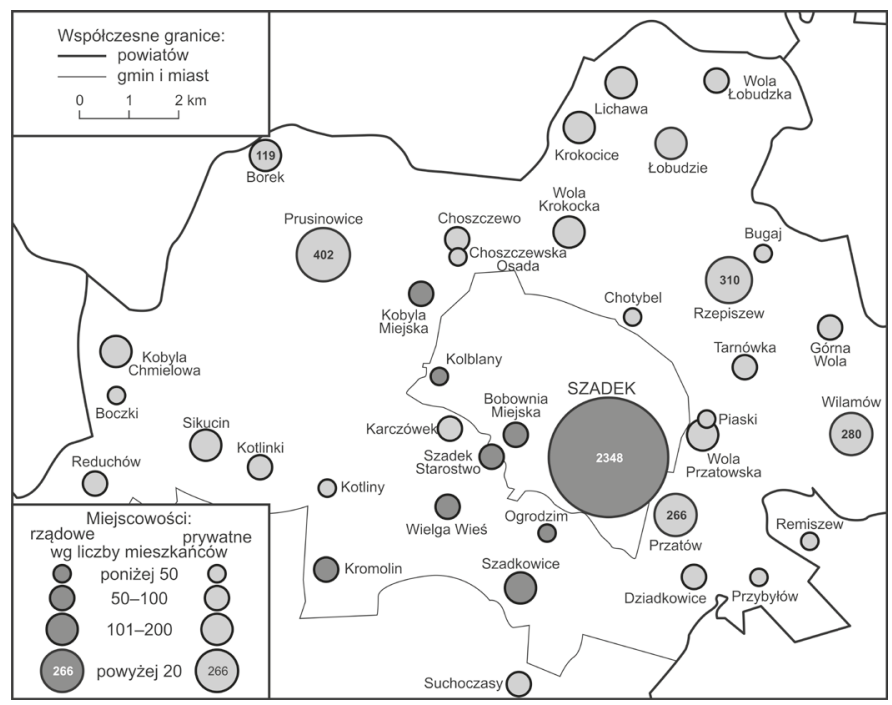

Ryc. 7. Rozkład przestrzenny jednostek osadniczych w gminie szadkowskiej według liczby mieszkańców ok. $1825 \mathrm{r}$.

Źródło: opracowanie własne na podstawie Tabella Miast, Wsi, Osad Królestwa Polskiego, z wyrażeniem ich położenia i ludności alfabetycznie ułożona w Biórze Kommisyi Rzadowey Spraw Wewnętrznych i Policyi, t. I, II, Warszawa 1827

\section{UWAGI KOŃCOWE}

Współczesna mapa osadnictwa obrazująca rozkład przestrzenny ludności i zabudowy w granicach gminy szadkowskiej, choć wyraźnie nawiązuje do tej sprzed dwustu lat, to jednak cechuje ją także szereg nowych elementów. O ile liczba ludności na tym terytorium w porównaniu z początkiem XIX w. wzrosła stosunkowo nieznacznie, bo zaledwie o $1 / 4$ (co w zestawieniu z przyrostem demograficznym na ziemiach polskich i w regionie łódzkim świadczy o wyraźnie malejącej roli tego obszaru), to liczba budynków mieszkalnych uległa zwielokrotnieniu i tylko na obszarach wiejskich gminy (bez Szadku) zwiększyła się ponad trzykrotnie (do blisko 1,5 tys.).

Struktura sieci osadniczej gminy szadkowskiej ukształtowana dwa wieki temu w znacznym stopniu przetrwała do dziś. Główne zmiany dotyczą przesunięć w potencjale ludnościowym poszczególnych miejscowości oraz przede wszystkim pojawienia się na mapie nowych punktów osadniczych, co było wynikiem procesów społeczno-ekonomicznych zachodzących od lat 60 . XIX w. do połowy $\mathrm{XX}$ w. Istotne znaczenie miały tu parcelacje - podział większych posiadłości ziemskich na mniejsze działki (parcele) i przekazywanie ziemi w drodze sprzedaży lub nadania nowym użytkownikom. Parcelacje na masową skalę rozpo- 
częły się po uwłaszczeniu chłopów w $1864 \mathrm{r} \cdot{ }^{15}$ Kolejna fala parcelacji ziemi pochodzącej z własności Skarbu Państwa, majątków tzw. martwej ręki i innych wielkich nieruchomości ziemskich, przypadała na okres II Rzeczypospolitej (lata 1919-1920 i po 1925 r.) ${ }^{16}$. Istotne znaczenie miał również dekret PKWN o reformie rolnej z 1944 r., na mocy którego w pierwszych latach po II wojnie światowej parcelowano przejęte majątki ziemskie ${ }^{17}$.

Przejawem zachodzących procesów osadniczych było pojawienie się nowych miejscowości. W drugiej połowie XIX w., już po powstaniu styczniowym, powstało Jamno. Mniej więcej w tym samym okresie pojawiły się miejscowości Karczówek Kolonia oraz wieś Cesarska Łaska (której nazwa w 1925 r. została zmieniona na Dziewulin), założone na gruntach bądź rozdanych włościanom, bądź przekazanych za zasługi wojskowym i urzędnikom. Pod koniec XIX w. w wyniku parcelacji majątku Krokocice zostały utworzone kolonie Łodzia i Tomaszew. Pełniący dziś funkcje sołeckie Antonin powstał pod koniec XIX w. wskutek wydzielenia $\mathrm{z}$ majątku Rzepiszew folwarku o tej nazwie ${ }^{18}$. W latach 1908-1910, po wykarczowaniu lasu, została utworzona wieś Kromolin Nowy (dziś pozostająca w granicach sołectwa Wielka Wieś), w której nadziały ziemi otrzymali głównie wojskowi. Inna miejscowość sołecka, Góry Prusinowskie została utworzona po I wojnie światowej, kiedy w wyniku reformy rolnej ziemię rozparcelowano i przekazano chłopom (małorolnym i bezrolnym) w zamian za spłaty drewnem pozyskanym z karczunku lasu na rozparcelowanym terenie. Takich nowych punktów osadniczych w gminie szadkowskiej, których historia sięga nie dalej niż końca XIX w., jest więcej, a wśród nich wszystkie wsie mające w nazwie określenie „nowe” (Boczki Nowe, Kromolin Nowy) czy „parcele” (Boczki-Parcela, Lichawa-Parcela, Prusinowice-Parcela, Wilamów-Parcela).

Niewiele zmieniła się pozycja Szadku, głównego ośrodka osadniczego, w relacji do pozostałych jednostek tworzących sieć osadniczą gminy, przynajmniej w kontekście formalnie obowiązującego terytorialnego podziału administracyjnego. Jednak $\mathrm{z}$ uwagi na procesy urbanizacyjne zachodzące $\mathrm{w}$ bezpośrednio przylegającym do miasta sołectwie Szadkowice-Ogrodzim (największym w gminie, liczącym blisko 0,9 tys. mieszkańców) i „de facto” stanowiącym jego część, należy stwierdzić, iż nastąpiła wyraźna koncentracja przestrzenna potencjału demograficznego w obrębie tej centralnej struktury miejskiej gminy. Analiza współczesnego rozmieszczenia ludności wskazuje również, iż w porównaniu z sytuacją sprzed dwustu lat swoją pozycję $\mathrm{w}$ sieci osadniczej poprawiły przede wszystkim te posiadające wykracza-

15 W Polsce pierwszych sporadycznych parcelacji związanych z oczynszowaniem chłopów dokonywano już w XVIII w. Do czasu powstania styczniowego parcelacje nie miały charakteru masowego.

16 W okresie międzywojennym pierwsza fala parcelacji przypada na lata 1919-1920 (w Polsce rozparcelowano wówczas ok. 19 tys. ha). Proces parcelacji ponownie nasilił się po $1925 \mathrm{r}$, po przyjęciu ustawy z 28.12.1925 r. o wykonaniu reformy rolnej. W sumie w okresie II Rzeczypospolitej rozparcelowano $2,65 \mathrm{mln}$ ha ziemi.

17 W latach 1944-1948 rozparcelowano w Polsce ok. 1,2 mln ha ziemi.

18 Folwark Bugaj istniał już w 1825 r. 
jącą poza XIX w. historię wsie sołeckie, które są położone w sąsiedztwie miasta, zwłaszcza od podlegającej silniejszym przekształceniom jego południowej strony (Wielka Wieś, Karczówek, Dziadkowice, Piaski, Kromolin Stary czy Przatów).

\section{Bibliografia}

Bandurka M., Zmiany administracyjne i terytorialne ziem województwa łódzkiego w XIX i XX w., Warszawa 1974.

Dziennik Prawa Księstwa Warszawskiego, t. I.

Marszał T., Gmina Szadek-zarys geograficzny, [w:] T. Marszał (red.), Leksykon solectw gminy Szadek, Łódź-Szadek 2004.

Marszał T. (red.), Leksykon sołectw gminy Szadek, Łódź-Szadek 2004.

Obwieszczenie Ministra Administracji i Cyfryzacji z dnia 4 sierpnia 2015 r. w sprawie wykazu urzędowych nazw miejscowości i ich części (Dz.U. z 2015 r., poz. 1636).

Szkutnik P., Źródła do dziejów Szadku znajdujące się w archiwach kościelnych, „Biuletyn Szadkowski" 2005, t. 5, s. 111-128.

Tabella Miast, Wsi, Osad Królestwa Polskiego, z wyrażeniem ich położenia i ludności alfabetycznie utożona w Biórze Kommisyi Rządowey Spraw Wewnętrznych i Policyi, t. I, II, Warszawa 1827.

Turczyn M., Szadek na tle podziałów administracyjnych Polski, „Biuletyn Szadkowski” 2001 , t. 1 , s. $65-74$.

[Artykuł wpłyną: marzec 2020; akceptacja: czerwiec 2020]

\section{SETTLEMENT STRUCTURE OF SZADEK REGION IN 1827}

\section{Summary}

The population and housing census conducted in Szadek region in 1824-1826, the results of which were published in 1827 in „Tabella Miast, Wsi i Osad Królestwa Polskiego", makes it possible to create an outline of the settlement structure of this part of the Kingdom of Poland at that time. The first part of this study provides a synthetic picture of settlement based on analysis of population and housing distribution. The second part presents a more detailed analysis of the settlement network within the boundaries of the present municipality of Szadek. The settlement network structure of this area, which was being formed up to the beginning of the $19^{\text {th }}$ century, has largely remained unchanged. The changes that have taken place concern population sizes of the existing localities and emergence of new settlements as a result of socio-economic processes taking place from the 1860 s to the mid- $20^{\text {th }}$ century.

Keywords: settlement, population, Szadek region 